\title{
第22回 日本血管病理研究会
}

\author{
会期：平成 29年11月 11日 \\ 会場：東邦大学医療センター大橋病院教育棟臨床講堂 \\ 当番世話人：高橋 啓（東邦大学医療センター大橋病院 病理診断科）
}

\section{症例(1)}

座長：川上民裕（聖マリアンナ医科大学 皮膚科）

\section{1. 逆流性食道炎に見られた小血管病変}

順天堂大学医学部附属練馬病院 病理診断科, 小児科 松本俊治, 浦 礼子, 小名木寛子, 坂口亜寿美, 小倉加 奈子, 丘 逸宏

\section{2. 電撃性紫斑病の一例}

岐阜大学医学部附属病院 病理部 小林一博, 久松憲治, 酒々井夏子, 宮崎龍彦

症例は 58 歳男性。2006年頃より痒疹があり加療して いた。その後，間質性肺炎としてプレドニゾロン投与が なされていた。2015年尿路感染症を主訴に近医入院し た。その 3 日後に全身紫斑が出現し, 播種性血管内凝固 異常症及び全身性紫斑から電撃性紫斑病と診断がなされ 当院に転院し加療された。紫斑部の皮膚症状は徐々に回 復し，回復後デブリードマンが行われた。その後全身症 状は回復したが, 亀頭の壊死が徐々に進行し1ヶ月後陰 茎の切除術が施行された。感染症により急速進行性に四 肢末端優位の虚血性壞死 (symmetric periphera lgangrene, SPG）は，(1)四肢遠位部の虚血性壊死で，(2)二肢以上が 同時に侵され，(3)近位の動脈閉塞を伴わないもの，と定 義される。そのうち感染症が原因と考えられる疾患を, 急性感染性電撃性紫斑病 (acute infectious purpura fulminans, AIPF）としている。採取されたいずれの検体にお いても，静脈血栓がみられ，静脈のうっ血が示唆される 組織像であった。後日行われた検查なども踏まえ本例に ついての報告及び考察を行う。
3. 広範な小腸壊死, 脾臓壊死, 両側腎臓分節状壊 死で発症した segmental arterial mediolysisの 1 剖検例

佐賀県医療センター好生館 病理部 木戸伸一, 森 大輔

高尿酸血症の他, 明らかな既往歴のない 48 歳男性。 亡くなる4日前に軽度の腹痛を認めていた。2日前に仕 事に行った直後より重度の腹痛・背部痛が出現し, 自制 困難となり当院に救急搬送される。来院時, 安静困難で 非麻薬性鎮痛薬でも痛みが改善しなかった。腹部造影 $\mathrm{CT}$ 検査では, 両側腎臟, 脾臟掞よび消化管に広範な造 影不良域を認めた。血栓症, NOMI（non-occlusive mesenteric ischemia), 腹腔動脈周囲の限局した大動脈解離等 による腹腔内臟器および腸管虚血を疑い血管造影検查が 施行された。大動脈に著変は見られなかったが，上腸間 膜動脈（SMA）や下腸管膜動脈（IMA）にspasmあるい は数珠状の変化を認め, 末梢の血流低下を認めた。また 脾動脈に動脈瘤があり，それより末梢が造影されなかっ た。SAM（Segmental Arterial Mediolysis）もしくはNOMI と判断され, SMA, IMAにカテーテル留置後, 血管拡張 薬，抗凝固薬，抗血小板凝集抑制薬の持続静注が行われ た。しかしながら, 血流の改善が得られず, 循環動態掞 よび呼吸状態が徐々に悪化し, CHDF 等の集学的治療が 行われたが，治療の甲斐なく死亡退院される。同日，死 因の解明目的に病理理解剖が行われた。剖検では，広範 な小腸壊死, 右側結腸虚血性変化, 脾臓壊死, 腎臓分 節状壊死を認めた。また, 上腸間膜動脈や両側腎動脈 の中膜筋層の変性や空胞状変化, 約 $1 \mathrm{~cm}$ 大の脾動脈瘤 を認め, これら血管の末消側内腔に血栓を認めた。特に SMAの末梢側に多数の血栓を認めた。従って, SAMに より筋型動脈の動脈壁が脆弱化し, 脾動脈㽣や動脈の 解離が起こり，末梢側に血栓を来たしたと考えられた。 SAMによる広範な腸管壊死の報告は稀であり, 文献的 考察を加え報告する。 


\section{川崎病}

\section{座長：宮崎龍彦（岐阜大学医学部附属病院病理部）}

\section{4.【Keynote Lecture】川崎病の“いま”：小児科医 の立場から}

東邦大学医療センター大橋病院 小児科 二瓶浩一

川崎病は1962年10月に「非猩紅熱性落屑症候群に ついて」と題して日本小児科学会千葉地方会にて初め て川崎富作博士が発表し，1967年に「指趾の特異的落 屑を伴う小児の急性熱性皮膚粘膜淋巴腺症候群：自験 例 50例の臨床的観察」（川崎富作，アレルギー 1967; 16: 178-222）として報告された疾患である。当初は予後 良好と考えられていたが，その後心臓突然死症例が複数 報告され冠動脈炎から冠動脈瘤をきたす疾患であるこ とが明らかとなった。1970年に研究班が発足し診断の

\section{心障害出現割合の年次推移} -第24回川崎病全国調査より-

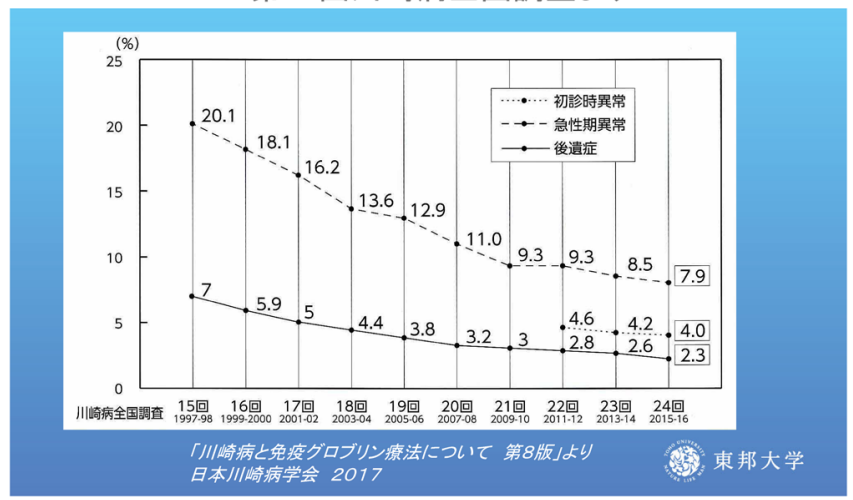

図 1 「初診時の異常」, 発病後1か月以内に出現した「急性 期の異常」および1か月以降も残存した「後遺症」は緩やか に減少している。

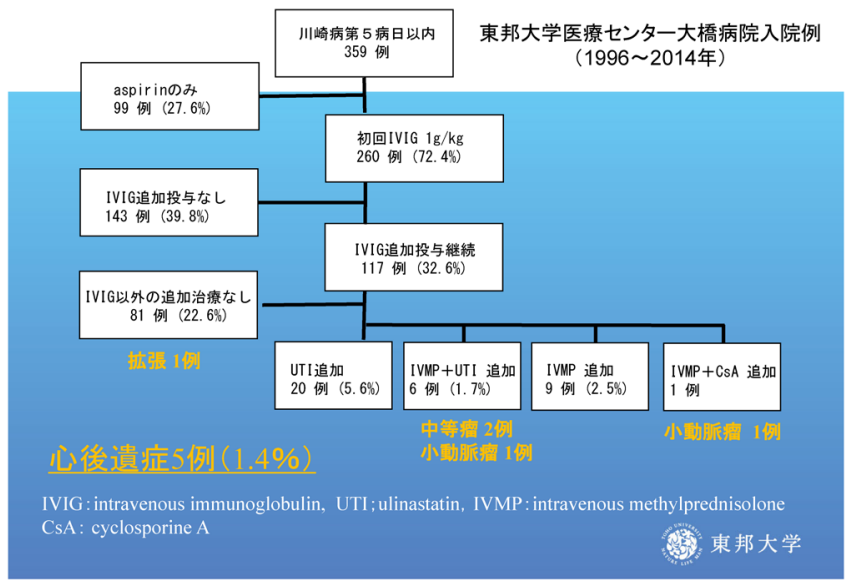

図 2 当科のガンマグロブリン $1 \mathrm{~g} / \mathrm{kg} /$ 回投与による治療経過 および成績を示す。
手引きが作成され，これに基づき第一回の全国調査が行 われた。以降，概ね 2 年に一度の全国調查が行われてお り，川崎病診療に携わる小児科医はこのデー夕を大変 重視して診療に携わってきた。第24回の調査結果が本 年9月に発表され，2015年は患者数，罹患率ともに史上 最高值を記録している。診断の手引きは 2002 年に第 5 版 が作成された。それから 15 年が経過し, 現行の手引き では診断が確定できない不全型の問題など，今日の診療 面に扔いて不備が目立ち始めている。このため診断の手 引きの改訂作業が日本川崎病学会を中心に始まった。川 崎病の臨床像, 診療の際に留意すべき検査值の動きや頸 部リンパ節の超音波所見, 頸部 CT 画像による咽後浮腫 所見の有無による鑑別などについて概説した。川崎病 は今日なお発症要因が明確ではない。一方，急性期治療 に関しては様々な報告が近年なされ，日本小児循環器 学会から 2012年に急性期治療ガイドラインの改訂版が 出された。川崎病心障害の頻度は確実に低下しつつあり （図 1), 今日の急性期治療の現状を当院での治療経過 . 成績を参考にお示しした（図2）。

\section{5. 川崎病超急性期の3例に共通する組織初見}

雄勝中央病院 検査科

増田弘毅

川崎病剖検例において 12 病日が最も早い冠状動脈瘤 発生症例である。我々が観察することができたそれより 早期の症例は 3 例（第一例； 5 歳 2 ケ月，男児，6病日死 亡例，第二例；10个月，男児，9病日死亡例，第三例；3 歳, 男児, 10 病日死亡例）である。我々は過去にこれら いずれの症例も詳細に検討し病理学的分析を行ってきた が, 冠状動脈中膜には (1) 水腫様変性, (2) 大型の単核細 胞の出現，(3) 通常の炎症細胞が出現しない（リンパ球 や好中球など）の所見が認められた。しかしこの変化は 著しい内膜肥厚を伴う内皮細胞直下のマクロファージ様 細胞の浸潤と外膜の著しい炎症細胞浸潤（リンパ球が中 心）に比較して軽微な特徵としてあまり真剣に取り上げ ることができなかった。つまりこの特徵を内膜炎と外膜 炎のハザマで生じた中膜の変化と認識していた。今回改 めてこの3例を観察し, この3つの特徵を再確認し, こ の病態が川崎病冠状動脈病変の中心なのではないかと考 え, その解釈を行った。(1)の水腫様変性の特徵は平滑 筋細胞の積み重なりがずれた様になり, 本来個々の平滑 筋細胞を取り囲んでいる微細な袋状の構築が膨張し， あ るものは破綻した状態であると推測した（図 1 ; 第一例 


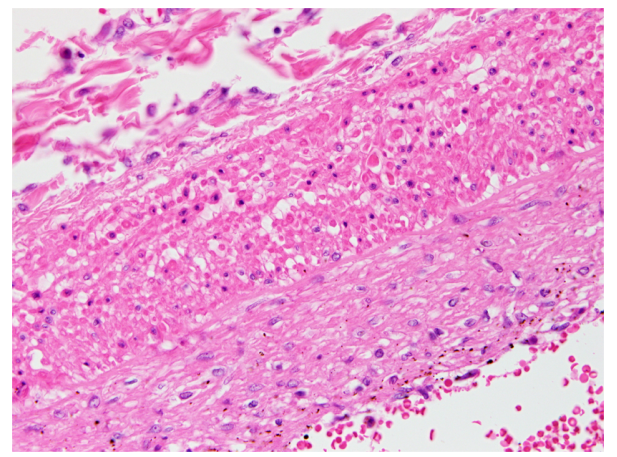

図 1 中膜平滑筋細胞の水腫様変性が全体に認められる。平 滑筋細胞は丸く核が目立ち, 大型の単核細胞様になってい る。炎症細胞浸潤はない, 第一例の右冠状動脈の中膜, HE, $\times 40)$

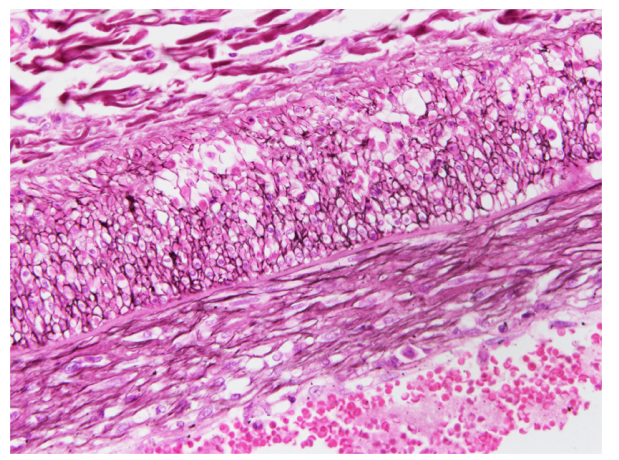

図2 平滑筋細胞を取り囲む様にPAM染色の線維が認めら れる。水腫性変性の強い場所では個々の取り囲みが癒合し て中膜の改築が生じている。第一例の右冠状動脈の中膜, PAM, $\times 40$ )

の右冠状動脈の中膜, HE, $\times 40$, 図 2 ; 同部のPAM染色, $\mathrm{x} 40$ ）。(2)大型の単核細胞の出現は楕円形から円形になっ た平滑筋細胞の増殖形態と考えられた。つまり平滑筋細 胞の増殖ステージであると推測した。（3）通常の炎症細 胞が出現していないのは, この病変が炎症細胞浸潤では ないことを示唆していると推測している。川崎病では発 症とともに冠状動脈が中膜平滑筋細胞の分裂増殖により 拡張リモデリングを始め, 完成するのが 12 病日であると 解釈できる。我々は病理解剖において動脈の平滑筋細胞 はほとんど増殖しないか, あるいは増殖しても稀である と考えて研究をしてきた。そのため川崎病冠状動脈病変 の本態がわからなかったのではないかと考えている。

\section{6. 川崎病における大型血管の組織学的変化}

東邦大学医療センター大橋病院 病理診断科 佐藤若菜, 横内 幸, 大原関利章, 榎本泰典, 高橋 啓

【目的】川崎病は, 乳幼児に好発する急性熱性疾患で あり，中小動脈を主体とした汎血管炎をきたす。これま
で死因に直結する冠状動脈の病理組織学的検討が主にな されてきたが，大動脈を含む大型血管については詳細な 検討がなされていない。そこで，川崎病剖検例の大動 脈を組織学的に検討し, 冠状動脈炎との関連を含めて 考察した。【方法】川崎病剖検例 34 例（急性期 16例, 遠 隔期 18 例）の大動脈㧍よび冠状動脈に対し，HE，EvG， $\mathrm{AM}$ 染色とリンパ球 (L26, CD3), マクロファージ $(\mathrm{M} \varphi)$ (CD68, CD163) の免疫染色を行い, 動脈壁構築（内弾 性板の断裂, 中膜の変性の有無）と動脈壁に打ける炎症 細胞浸潤の局在および程度について検討した。【結果】 大動脈は全例，動脈壁構築の破壊はなく，急性期例で軽 度の炎症細胞浸潤を認めた。浸潤細胞は $\mathrm{M} \varphi$ が主体で好 中球は見いだせなかった。リンパ球浸潤は 11 例で確認 された。炎症細胞は病初期には内膜と外膜に分布し, そ の後中膜に波及し全層に至っていた。遠隔期例では炎症 細胞浸潤はなく, 線維化も認められなかった。一方, 冠 状動脈ではほとんどの例で動脈壁構造の破壊があり，急 性期では壁全層に及ぶ著しい炎症細胞浸潤がみられた。 炎症細胞浸潤の経時的変化は大動脈とほほ同様であっ た。【考察】冠状動脈に比して大動脈の炎症は軽度であ るが，急性期には $\mathrm{M} \varphi$ 主体の炎症が生じており，その経 時的変化は冠状動脈炎とほぼ一致すると考えられた。大 動脈から分岐する血管や大動脈起始部の評価も加えて報 告する。

症例(2)

座長：菅野祐幸（信州大学学術研究院医学系医学部 病理組織学教室)

\section{7. 心サルコイドーシスに対し植込型補助人工心臓を 長期装着し，消化管出血を繰り返した一剖検例}

1 愛媛大学大学院医学系研究科 解析病理学講座, 2 愛媛 大学大学院医学系研究科 心臟血管呼吸器外科学, 3 愛 媛大学医学部附属病院 病理診断科

倉田美恵 ${ }^{1}$, 浪口謙治 ${ }^{2}$, 泉谷裕則 ${ }^{2}$, 上田康雄 ${ }^{3}$, 増本純也 ${ }^{1}$

1997年に我が国で臟器移植法が制定されて以来, 心 臟移植は 2 年以上の移植待機が必要となった。現在約 $90 \%$ の患者が補助人工心臓（VAD）を心臓移植への橋渡 しとして要している。しかし，長期VADを装着する際， 遠隔期合併症が問題となっている。今回私達は心臟移植 待機中に植込み型LVADを長期装着し, 繰り返寸消化管 出血と誤嚥性肺炎のため死亡した患者様の剖検を経験し たため, 報告する。症例は 60 歳代男性。死亡約 6 年前に 
心不全を発症し，拡張型心筋症として保存的に加療され た。感染を契機に心不全が増悪し, 診断後約半年後に体 外式左室補助人工心臓（LVAD）植元込み，三尖弁輪形 成術，僧帽弁輪形成術を行われた。その際の心筋生検 で心サルコイドーシスを診断された。PET-CTにて活動 性の集積はなくステロイド治療は行われなかった。経過 中心機能が改善しなかったため, 心臓移植適応であり, ネットワーク登録（Status分類1）を完了した。死亡約 3 年前に当院が植込型 LVAD実施施設の認定を受け, 同年 に体外式LVAD から植込型LVAD（Jarvik2000）に変更し た。経過中, 脳虚血発作を複数回認め, 全身の活動度は 低下傾向であった。植込み術後約 100 日頃から消化管出 血，誤嚥性肺炎を繰り返すようになり，死亡約 2 年前に Status 分類 1 から 3 に変更された。死亡前日に嘔吐，誤 嚥，酸素化低下，腹部膨満あり， CTで小腸イレウスが 診断された。集約的治療を行われたが敗血症性ショック となり, 植込々型LVAD装着術後1219日で永眠された。 病理解剖では肺，全身リンパ節，甲状腺，肝臓，脾臟に 類上皮肉芽腫を認め, 全身性サルコイドーシスであっ た。心臟には不規則な線維化が認められたが, 肉芽腫は 認められなかった。消化管は小腸に領域性を持った色調 変化が認められ，組織学的には同部位の粘膜上皮は脱落 し虚血性腸炎たった。肉眼的所見にそしい粘膜において も粘膜固有層内の脈管拡張が認められ，繰り返す消化管 出血はこれらの intestinal angiodysplasia も一因と考えられ た。

\section{8. 右上肢のKlippel-Trenaunay-Weber症候群に異 時性多発性の動脈瘤を生じた一例}

1 宮崎大学医学部病理学講座 構造機能病態学分野, ${ }^{2}$ 宮 崎大学医学部附属病院 病理診断科, 3 宮崎大学医学部 外科学講座 心臓血管外科学分野

魏 峻洸 ${ }^{1}$, 山下 篤 ${ }^{1}$, 佐藤勇一郎 ${ }^{2}$, 白崎幸枝 ${ }^{3}$, 古川 貢之 ${ }^{3}$, 中村栄作 ${ }^{3}$, 中村都英 ${ }^{3}$, 浅田祐士郎 ${ }^{1}$

Klippel-Trenaunay-Weber症候群は混合型脈管奇形と片 側四肢の肥大症をきたす稀な先天疾患である。脈管奇形 は毛細血管奇形と静脈奇形の混合型が典型的であり，動 脈病変をきたさないとされる。右上肢に異時多発性の 動脈瘤を生じた Klippel-Trenaunay-Weber 症候群の一例を 報告する。症例は 40 歳代女性。特記すべき既往歴, 家 族歴なし。生下持より右上腕の静脈瘤を指摘されてい た。10歳代時に右頚部に拍動性の腫瘤を自覚し, 澒横 動脈に連続する瘤状病変を指摘された。右上肢全体に広
がる静脈瘤様の血管拡張と軽度の右上肢の伸長を認めた ため, Klippel-Trenaunay-Weber 症候群を背景とした脈管 病変と判断された。破裂の危険性を考慮し瘤状病変に対 して外科的切除を施行された。40歳代時に再び右䅡部 に拍動性腫瘤を自覚し, 右鎖骨下動脈, 右上腕動脈分枝 それぞれに連続する複数の瘤状病変を指摘された。右鎖 骨下動脈病変に対して外科的切除が施行され, 右上腕動 脈病変に対して経カテーテル塞栓術が施行された。瘤状 病変の病理像は, 海綿血管腫状の病変と線維性結合組織 から成り，一部に病変に巻き込まれた弾性動脈壁を認め た。瘤壁内腔にはフィブリン, 線維芽細胞を主体とする 器質化血栓がみられた。Klippel-Trenaunay-Weber 症候群 では混合型脈管奇形をきたすことが知られているが，動 脈瘤形成を形成する症例は極めて稀である。本症例は, 海綿状血管腫状病変の進展が, 異時多発性の動脈瘤形成 に関与したと考えられた。

\section{9. 大腸癌に合併した早期の腸間膜静脈硬化症と考 えられる1例}

${ }^{1}$ 信州大学病理組織学教室, ${ }^{2}$ 佐久医療センター 病理診 断科

一萬田正二郎 ${ }^{1,2}$, 塩澤 哲 ${ }^{2}$, 菅野祐幸

【症例】60歳代，女性。【既往歴】更年期障害。【現病 歴】定期にて便潜血陽性を指摘され，佐久医療センター を紹介受診した。精査の結果，上行結腸に2型病変を認 め, 右半結腸切除術が施行された。な抢, 術前の CT 検 查で明らかな石灰化は指摘されていなかった。【病理所 見】軽度黒色調を示す大腸粘膜を背景に，2型病変を認 めた。組織学的には adenocarcinoma（tub2>por2）であっ た。一方, 粘膜下層〜漿膜下層内に硝子化した静脈が多 数観察された。同病変はマッソン・トリクローム染色で 鮮やかな緑色に染色され，コンゴーレッド染色陰性であ ることから，膠原線維の沈着と判断した。また，上皮直 下及び粘膜固有層内の血管周囲には带状の好酸性沈着物 が観察され，同沈着物も膠原線維であった。腸間膜静 脈硬化症（MP）が疑われたため，腸間膜を主体に標本 を作製したところ，硝子化を示す腸間膜静脈に最大で $1 \mathrm{~mm}$ 程度の石灰化が観察された。【考察】MPは，1991 年に小山らが初めて報告して以来, 現在まで本邦例を中 心に，100例以上が報告されている。MPは腸間膜静脈 に特徵的な石灰化を来すことが知られているが，早期の 段階では石灰化を欠くとされている。さらに，腹部症状 の出現頻度は石灰化の進行と相関するため, 早期の状態 
では臨床的な術前診断は困難であり, 病理組織学的な検 索が診断に不可欠と考えられる。近年，MP と山㭾子を 含む漢方薬の関連が指摘されており，内服歴がある患者 では内服中止が推奨されている。本例でも，更年期障害 に対し山栃子を含む漢方薬（加味逍遥散・加味帰脾湯） が10年以上処方されていた。結腸手術材料（特に近位 結腸）に明らかな石灰化を欠くものの著明な静脈壁の肥 厚や硝子化が見られた場合はMPを疑い，内服薬の確認 を行うことが重要と考えられた。

\section{中枢神経血管炎}

\section{座長: 石津明洋（北海道大学大学院保健科学研究院 病態解析学分野)}

\section{0. 原発性中枢神経血管炎に類似した脳病理所見を 呈した巨細胞性動脈炎の剖検例}

1 順天堂大学 膠原病内科学講座, ${ }^{2}$ 順天堂大学 人体病 理病態学講座, ${ }^{3}$ 順天堂大学 脳神経内科学講座, ${ }^{4}$ 順天 堂大学医学部附属越谷病院 脳神経内科

安倍能之 ${ }^{1}$, 山下淳史 ${ }^{2}$, 今 高之 ${ }^{1}$, 遠藤由佳梨 ${ }^{1}$, 浅 井悠貴 ${ }^{1}$, 上野祐司 ${ }^{3}$, 高梨雅史 ${ }^{4}$, 多田久里守 ${ }^{1}$, 山路 健 $^{1}$, 服部信孝 ${ }^{3}$, 八尾隆史 ${ }^{2}$, 田村直人 ${ }^{1}$

症例は64歳男性。X-11月に転倒・頭部外傷を受傷し, 受傷後の慢性頭痛に罹患。X-9月の再診時で炎症反応高 值を認め, X-8月に入院となった。頭部3DCTA で左鎖骨 下動脈と胸部大動脈壁肥厚を認め, PET-CTで外眼筋 · 上行大動脈・両鎖骨下動脈 - 両総䅡動脈 - 側頭動脈に FDG の集積を認めた。X-7月より PSL60 mg/day $(1 \mathrm{mg} / \mathrm{kg} /$ day）で治療開始。側頭動脈生検でも浅側頭動脈に巨細 胞浸潤が確認され，巨細胞性動脈炎の確定診断となっ た。X-5 月 PSL $37.5 \mathrm{mg}$ 内服中に不明言動が出現, 頭部 MRI で亜急性期脳梗塞の診断となり，3か月前と比較し 両側椎骨動脈の描出不良, 右内䅡動脈狭窄を認めたこと から，ステロイドフルパルス療法の追加が選択された。 経口ステロイド増量は行わず経過観察の方針となった。 脳梗塞の再発・症状増悪を認めずX-3月にリハビリテー ション病院へ転院。しかしX-2, -1月と繰り返す新規脳 梗塞に罹患, $\mathrm{X}$ 月に意識レベル低下 $(\mathrm{JCS} 300)$, 対光反 射消失，血圧低下を認为当院搬送。頭部MRIにて両側 大脳・小脳の広範な脳梗塞を認め緊急入院となったが, 改善を得られず $\mathrm{X}+1$ 月死亡した。剖検所見では，前・ 中 · 後大脳動脈領域の大脳皮質, 脳底動脈領域の橋中小 脳脚，小脳，穿通枝領域の淡蒼球に梗塞を認め，急性期
のものから発症数か月経過したものまで混在を認めた。 脳実質内の細小血管周囲や血管壁にはリンパ球主体の炎 症細胞浸潤が見られた。内頚動脈や中大脳動脈, 大動 脈, 腕頭動脈, 両側総澒動脈, 鎖骨下動脈, 総腸骨動脈 には秥状硬化性変化を認めるのみであり，いずれも中膜 の弾性線維や平滑筋線維の走行は保たれて抢り, 巨細胞 を含む炎症細胞浸潤や線維化には乏しかった。巨細胞性 動脈炎と臨床診断され加療された症例が, 臨床経過掞よ び病理所見として原発性中枢神経血管炎に類似した所見 を呈したことから，貴重な症例として報告する。

\section{1. 慢性髄膜炎に伴う再発性脳梗塞を呈した中枢神 経系血管炎の一例}

${ }^{1}$ 杏林大学医学部 神経内科, ${ }^{2}$ 杏林大学医学部 脳神経 外科, ${ }^{3}$ 杏林大学医学部 病理学, ${ }^{4}$ 杏林大学医学部 リ ウマチ膠原病内科

中島昌典 ${ }^{1}$, 茂吕直紀 ${ }^{1}$, 白鳥嵩之 ${ }^{1}$, 上月直樹 ${ }^{1}$, 綾野水 樹 ${ }^{1}$, 市川弥生子 ${ }^{1}$, 山岸夢希 ${ }^{2}$, 豊田研隆 ${ }^{2}$, 齊藤邦昭 ${ }^{2}$, 塩川芳昭 ${ }^{2}$, 長濱清隆 ${ }^{3}$, 柴原純二 ${ }^{3}$, 高橋孝幸 ${ }^{4}$, 池谷紀

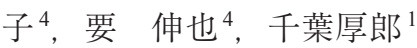

【症例】53歳女性。【主訴】一過性の両下肢硬直・少 い, 湢吐。【既往歴】先天性左股関節症・右膝関節症。2 年前: 左橋梗塞, 右橋梗塞。 1 年前 : 左線条体梗塞。【現 病歴】再発性脳梗塞のため, アスピリン $100 \mathrm{mg} /$ 日とシ ロスタゾール $100 \mathrm{mg} /$ 日を内服中。入院 2 週間前から動作 緩慢や食思不振，構音障害の増悪あり。入院当日に主訴 を認めたため, 当院へ救急搬送された。頭部MRIで右 前小脳動脈領域に梗塞を認め, 同日入院とした。【経過】 第3 病日に施行した頭部造影 MRIで脳幹主体に髄膜の多 発結節を伴う造影効果を認めた。䯣液検査で糖低下を伴 う単核球優位の細胞数上昇を認めた。結核性や真菌性を 考慮して投薬を開始しつつ, 各種培養検査を施行したが 検出なし。自己免疫性の鑑別として, 自己抗体などは特 異的所見を示さず。脳アミロイド血管症を考慮したトラ ンスサイレチン遺伝子解析, 皮膚生検はいずれも有意所 見なし。アスピリンを継続していたが，第29病日に右 前小脳動脈領域に新規梗塞を認めた。また頭部MRAで 進行する血管狭窄所見を認めた。第 50 病日に脳生検を 実施し, 脳表に多核巨細胞を伴う類上皮細胞性肉芽腫を 認めた。壊死性血管炎やアミロイド, 病原体は検出され なかった。第 70 病日からプレドニゾロン $1 \mathrm{mg} / \mathrm{kg}$ 投与を 開始し, 髄膜炎は改善傾向を示した。その後, 腰痛に伴 う血圧上昇から脳出血を合併し, 左後下小脳動脈領域に 
新規梗塞を認めた。【考察】中枢神経系血管炎は原因不 明の稀な疾患で，脳・脊髄に限局する。全身性血管炎の 部分症状として生じたもの，感染症，全身疾患に伴う血 管炎の除外が必要である。典型的な病理所見は髄膜や脳 実質内に多核巨細胞を伴う分節性の肉芽腫性血管炎を認 める。本症例は病理所見で肉芽腫を認めたが血管炎は明 らかでなかったものの，画像上血管狭窄所見から臨床的 に中枢神経系血管炎と判断し, 治療介入したが効果を得 るのに難渋している。診断・治療への討議を希望する。

\section{Granulomatous angiitis of the central ner- vous system が疑われた一例}

仲田成美 ${ }^{1,3}$, 古賀道明 ${ }^{2}$, 池田栄二 ${ }^{3}$

${ }^{1}$ 山口大学医学部附属病院 病理診断科, ${ }^{2}$ 山口大学大学 院医学系研究科 神経内科学講座, ${ }^{3}$ 山口大学大学院医 学系研究科・病理形態学講座

【症例】78歳男性。左視野狭窄，頭痛を主訴に近医受 診し, MRIで右後頭葉に造影効果のない境界不明瞭な T2WI高信号域を認め, 当院紹介となった。経過観察中 に脳浮腫の増悪により緊急入院となり，開頭下右後頭葉 脳生検が行われ, granulomatous angiitis of the central nervous systemが疑われた。また, ${ }_{18} \mathrm{~F}$-FDGPET/CTで肺門部 にFDGの集積があり，気管支肺胞洗浄液中の $\mathrm{CD} 4 / 8$ 比 が上昇し，末梢神経伝導検査で伝導ブロックを伴う multimononeuropathyの所見が見られたことから，全身性サ ルコイドーシスを疑われたが, 組織学的な確診には至ら なかった。シクロホスファミドパルスを行い, 症状改善 した。その後 1 年経過するが，画像的にも脳脊髄液検査 でも病勢の再増悪はなく, 経過は良好である。【病理所 見】クモ膜下腔及びVirchow-Robin腔に顕著なリンパ球, 組織球浸潤を認め, 肉芽腫の形成も見られる。それら の炎症細胞浸潤が，血管に局在する傾向があり，サルコ イドーシスの診断には至っていないため, granulomatous angiitis of the central nervous systemを第一に考元る。本症 例を granulomatous angiitis of the central nervous system とし てよいか,ご教示頂きたい。
高安動脈咨と巨細胞性動脈炎，大型血管炎をもう一 度考える

座長：植田初江（国立循環器病研究センター 病理部） 座長：高橋 啓（東邦大学医療センター大橋病院 病 理診断科)

\section{3.【基調講演】高安動脈焱と巨細胞性動脈炎の病 態と治療}

国立循環器病研究センター研究所 血管生理学部 中岡良和

高安動脈炎は，大動脈とその一次分枝に狭窄・閉塞性 または拡張性の病変を炎症性にきたす難病指定疾患で ある。我が国の患者数は約 6,000 名で，若年女性に発症 が多い。血中の IL-6、TNF- $\alpha$, IL-12濃度の上昇が報告さ れて, 炎症性サイトカインの病態への関与が示唆され る。ステロイドは最も確実な治療効果を発揮する治療薬 だが, 高安動脈炎では約半数で再燃が見られる。進行す ると大動脈瘤，大動脈弁閉鎖不全，脳梗塞などをきた すため, 有効性の高い治療が必要と考えられる。HLAB52が病態と関連すると以前から報告されていたが，最 近のゲノムワイド関連研究から IL-12B 及びMLX遺伝子 領域の一塩基多形が高安動脈炎の発症と関連すると報告 されている。巨細胞性動脈炎（GCA）は唄頭動脈を主 とする頭蓋領域の動脈に狭窄性，拡張性の病変をきたす わが国では稀な疾患とされ，2015年度受給者数は199人 で, 患者は50歳以上で発症する。1990年米国リウマチ 学会分類基準で分類してから, 頭蓋型巨細胞性動脈炎 （Cranial GCA）と大血管型巨細胞性動脈炎（large-vessel GCA, LV-GCA）に分類される。Cranial GCA が側頭動脈 · 眼動脈等の頭蓋領域の動脈に病変がとどまるのに対し て, LV-GCAでは頭蓋領域の動脈に加えて, 大動脈，鎖 骨下動脈，総計動脈等の頭蓋領域外の動脈に病変をもた らす。近年，LV-GCAが予想よりも多く, Cranial GCAよ りも好発年齢は若い傾向にあることが報告されている。 高安動脈炎と GCAの 2 疾患は, 病理像で巨細胞を伴う 肉芽腫性血管炎を呈する共通点を有する。最近, 高安動 脈炎と GCAに対して抗IL-6受容体抗体トシリズマブの 治験がわが国と欧米でそれぞれ行われて，わが国では本 年 8 月に両疾患に薬事承認がなされた。今後, これら 2 疾患の治療は大きく変わると期待される。 


\section{4.【基調講演】病理形態からみた大動脈炎：高安 動脈炎と巨細胞性動脈炎の異同を中心に}

1 榊原記念病院 病理部, 2 東京都監察医務院 村井達哉 1,2

高安動脈炎および巨細胞性動脈炎は，いずれも大動脈 などの大型血管に巨細胞を伴った肉芽種性炎症を生じる 疾患として知られているが，これら2疾患の臨床像には 異なる点が多い。またこれら 2 疾患以外にも，巨細胞を 伴う肉芽種性炎を大型血管に生じうる疾患としては梅 毒性大動脈炎，血管ベーチェット病，サルコイド動脈炎 などがある。今回は, これらの肉芽種性大動脈炎（剖検 例・外科手術例）の病理所見を提示し，各疾患に扮ける 病理形態像の比較を行った。その結果, 高安動脈炎拈よ び梅毒性大動脈炎では，炎症は大動脈外膜より主として Vasa vasorum 周囲を中心に中膜外層へのひろがりを示す のに対して，巨細胞性動脈炎では外膜や中膜外層が保た れながら中膜中層〜内層に炎症が観察される場合が少な からずあり，両者の病理形態はやや異なるものと考えら れた。また, 高安動脈炎や梅毒性大動脈炎では, 線維化 の進行が巨細胞性動脈炎よりも高度であり，このことが 巨細胞性動脈炎に比して高安動脈炎や梅毒性大動脈炎で は大動脈解離の合併が少ないことの一因ではなからうか と考えられた。

\section{1 施設 20 年間で経験した高安動脈炎の病理学的 検討}

国立循環器病研究センター病院 病理部 松本 学, 大郷恵子, 池田善彦, 植田初江

高安動脈炎（TA）は，大血管とその分岐を中心とす る原因不明の血管炎であり，本邦に多いと言われてい る。1997年から 2016年の 20 年においてTAもしくはその 疑いで動脈瘤切除術が行われた 63 症例（M/F;9/54, age; (20-90y/o, mean $58.3 \mathrm{y} / \mathrm{o})$ について病理学的な検討を 行った。5 年毎の病理組織検体数内訳は, 1997-2001：12 例 $(19 \%) ， 2002-2006$ 年：17例 $(27 \%) ， 2007-2011$ 年： 20 例 $(32 \%) ， 2012-2016$ 年：14例（22\%）であった。基 礎疾患・既往としては，高血圧 40 例 $(63.5 \%)$, 糖尿病 4 例 $(6 \%)$ ，脂質異常 13 例 $(21 \%), \mathrm{CKD} 7$ 例 $(11 \%)$ ，大 動脈弁置換術後9例（14\%）であった。大動脈分岐血管 の狭窄ないし閉塞は 26 例 $(41 \%)$ でみられ，うち鎖骨下 動脈狭窄が19例（73\%）と高頻度であった。術前にTA の診断を受けていた症例は 28 例（44\%），ステロイド加
療は26例（41\%）に行われていた。動脈瘤の部位は，上 行-弓部大動脈瘤 40 例 $(63 \%$, mean 径 $54 \mathrm{~mm})$, 下行大動 脈瘤 13 例 (21\%, mean 径 $55 \mathrm{~mm})$, 腹部大動脈 9 例（14\%, mean径 $47 \mathrm{~mm}$ ) であった。病理学的には, 中膜破壊が 中心の急性期の炎症像を呈する症例は少なく（9例， 14\%)，慢性期の症例がほとんどであり，動脈瘤壁は， 典型的な中膜の虫喰像やリンパ球浸潤を伴う外膜肥厚に 加え, 呫状硬化病変も認め複雑な所見であった。TAは, 血管の狭窄病変が有名であるが，狭窄時期が明らかでな く, 長期間の罹病を経て動脈瘤化した場合には, 臟器症 状にそしく発見が遅れる傾向にあることが予想された。 狭窄・閉塞症状がなく経過する例も存在し，とくに高齢 者に抢いては孤立性動脈炎や他の血管炎の鑑別も必要と 考えられた。

\section{6. 冠動脈瘤を伴った高安病の高齢女性剖検例}

公立学校共済組合関東中央病院 病理科 岡 輝明

病歴概略。84歳代，女性。81歳時に胸部大動脈瘤と 大動脈弁閉鎖不全症を指摘されたが経過観察されてい た。慢性心不全の増悪により入退院を繰り返した。半年 前に硝酸剤で改善する胸部圧迫感を自覚するようにな り, その後下腿浮腫や呼吸困難が出現するようになり大 動脈閉鎖不全症による慢性心不全の急性増悪と判断され 入院。既往歴には脊椎カリエス, 大腿澒部骨折があり, 高血圧, 糖尿病, 高尿酸血症で治療中。家族歴, 生活歴 として，母親が心臟病，哭煙（BI: 1240），飲酒せず。入 院時, 全身の浮腫が観察され, 画像所見から両側胸水, 肺うっ血, 右肺無気肺, 著明な心拡大, 大動脈抢よび総 腸骨動脈の拡張，左肺動脈血栓などが認められ，大動脈 弁閉鎖不全症による慢性心不全の増悪と考元, Heparin, 硝酸剂，利尿薬による治療が開始され，肺うっ血およ び浮腫は改善した。しかし, 胸痛発作が出現し心電図 上V4-6でST低下が認められたため冠動脈攣縮性狭心症 の合併を考えて Ca拮抗薬の投与を開始したところ症状 は安定し, 経過良好であったが, 第36病日に突然の呼 吸停止を来し，蘇生に反応せず逝去された。剖検所見概 略。

1. 高安病（大動脈，総腸骨動脈，腕頭動脈，鎖骨下 動脈，冠動脈瘤）

2. 大動脈拡張による大動脈弁閉鎖不全

3. 左心室拡張を伴う肥大

4. 肺気腫 
5. 胸膜アスベスト斑

\section{7. 大動脈解離により死亡した無治療巨細胞性動脈 炎の 1 剖検例}

1 佐賀大学医学部 病因病態科学講座, ${ }^{2}$ 新古賀病院 病 理診断科

高瀬ゆかり ${ }^{1}$, 徳永 藏 $^{2}$, 相島慎一 ${ }^{1}$

\section{8. 高安大動脈炎と巨細胞性動脈炎の出現細胞の免 疫組織化学的差異}

${ }^{1}$ 東京医科大学 分子病理学分野, ${ }^{2} \mathrm{NTT}$ 東日本関東病院 病理診断科, ${ }^{3}$ 東京医科大学 人体病理学分野

倉田 厚 ${ }^{1}$, 齋藤 彰 $^{1}$, 藤田浩司 ${ }^{1}$, 橋本浩次 ${ }^{2}$, 堀内 啓 ${ }^{2}$, 長尾俊孝 ${ }^{3}$, 黒田雅彦 ${ }^{1}$

【背景】高安大動脈炎（TA）と巨細胞性動脈炎 （GCA）は，ともに大型血管炎であり，発症年齢の差を 除いては臨床的・病理的に共通項が多いため, 近年, 両 者を同一疾患とみなす意見もある。そこで，両者の組 織に現れる平滑筋,リンパ球, 単球由来細胞の免疫組織 化学染色を施行した。【対象と方法】9例の TA と 5 例の GCAの組織を用いた。TAに関しては中膜の厚さに対す る内膜扮よび外膜の厚さで時相を推定した。免疫染色と して $\alpha$-SMA, h-Caldesmon (平滑筋); CD3, CD4, CD8（T リンパ球)；CD20, CD79a, CD138（Bリンパ球掞よび形質

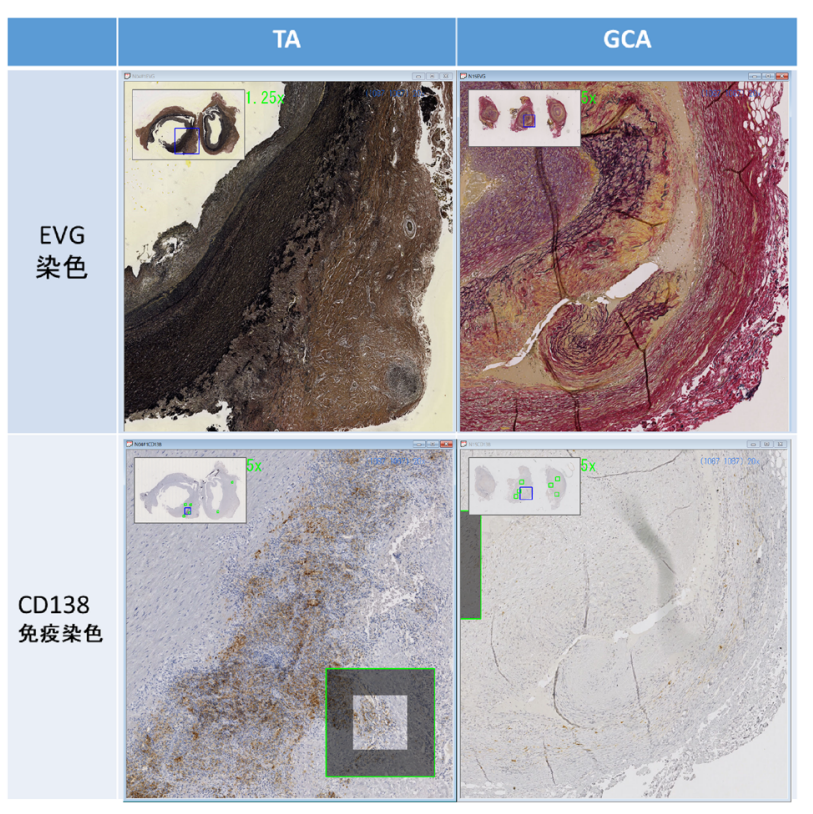

図1 TAとGCAの代表例における, EVG染色とCD138免 疫染色。TAの慢性期では中膜外側よりの破壊が認められる (上段左)。中膜・外膜における CD138陽性の形質細胞は TA で多く認められるがGCAでは乏しい (下段)。
細胞)； CD68, S100, fascin（単球由来細胞）を用いた。平 滑筋以外の細胞（炎症性細胞）では内膜・中膜・外膜に 分けて単位面積当たり陽性数を計測した。【結果】TAは 中膜に対する内/外膜の壁厚比から, 各々 3 例の急性期, 慢性期, 瘏痕期に分類された。この順で内膜の $\alpha$-SMA に対するh-Caldesmon陽性率が上昇し，平滑筋が成熟し ていくと考えられた。TAの巨細胞は急性期のみで出現 した。TAの急性期と慢性期では中膜外側からの破壊が 認められた（図1）。TAの痏痕期は炎症性細胞がそしい ため免疫染色での炎症性細胞計測から除外した。炎症性 細胞に関して, TA $(\mathrm{n}=6)$ は GCA $(\mathrm{n}=5)$ に比して, 外 膜での陽性細胞が多い, 中膜でのB細胞および形質細胞 の比率が高い（図1), 内膜での陽性細胞が少ない（除： CD68 と CD138 陽性細胞) などの特徵が見出された。ま た，CD4/8比はTAよりも GCAで高かった。【結論】TA は外膜側から炎症が生じるが GCA は内膜側から生じる, $\mathrm{TA}$ はB 細胞・形質細胞系の関与が高いが GCAでは低 い, などの特徵から, 両者は異なる疾患とみなすことが 妥当と考えられる。

\section{9. 梅毒性大動脈炎の一手術例}

${ }^{1}$ 東邦大学医療センター大橋病院 病理診断科, ${ }^{2}$ 東邦大 学医療センター大橋病院 心臓血管外科

大原関利章 ${ }^{1}$, 佐藤若菜 ${ }^{1}$, 横内 幸 $^{1}$, 榎本泰典 ${ }^{1}$, 清原 久貴 ${ }^{2}$, 高遠幹夫 ${ }^{2}$, 山下裕正 ${ }^{2}$, 尾㠃重之 ${ }^{2}$, 高橋 啓 $^{1}$

【症例】49歳, 男性。以前から動悸と息切れがあり, 近医にて大動脈弁閉鎖不全症（AR）を指摘されていた。 最近，息切れが増強したため当院を紹介受診された。心 エコーでは心機能低下（EF 40\%）と左室拡大（LVDd $70 \mathrm{~mm}$ ), 左冠尖の短縮に伴う AR IV 度を認めた。胸部 CTでは, 上行大動脈拡大 $(47 \times 51 \mathrm{~mm})$ を認めた。自己 心膜を用いた大動脈弁再建術 - 部分弓部大動脈人工血管 置換術が施行された。病理検体として上行大動脈と大動 脈弁, 心囊膜が提出された。病理所見】肉眼的に大動 脈では内腔の拡張と壁肥厚が見られた。組織学的には 中膜栄養血管に沿って好中球を主とし, 組織球, リンパ 球，形質細胞などの浸潤が見られた。多核巨細胞が少数 散見されるが，明らかな肉芽腫形成にはそしかった。中 膜平滑筋の凝固壊死や中膜弾性線維の断裂が広範に認め られた。内膜には線維性肥厚が目立った。炎症細胞浸潤 は内膜にも及び，一部で内膜表面に達していた。外膜 には著明な線維性肥厚と腫大したリンパ滤胞, 形質細 胞浸潤が見られた。高安動脈炎, 感染性大動脈炎, $\mathrm{IgG} 4$ 
関連大動脈炎等を考えていたところ，担当医から梅毒 陽性との臨床情報を得た。免疫染色にて大動脈壁に抗 Treponema抗体陽性のらせん様構造物が確認でき, 梅毒 性大動脈炎と診断した。【まとめ】梅毒性大動脈炎は高 安大動脈炎と類似する組織像を呈し, 両者の鑑別は梅毒 感染の有無によってなされることが多い。高安大動脈炎 に打いても肉芽腫性炎症だけでなく多彩な炎症像を呈す ることが知られており, 組織像から梅毒性大動脈炎と高 安大動脈炎をはじめとする他の大動脈炎が鑑別可能であ るのか否か御教示いただきたい。わが国における梅毒 は2011年以降，急増して打り，大動脈炎の診断の際に は常に念頭に置くべき疾患であることを再認識させられ た。

\section{小型血管炎}

座長：湯村和子（国際医療福祉大学病院予防医学セ ンター 腎臓内科)

座長: 倉田美恵（愛媛大学大学院医学系研究科解析 病理学講座)

\section{ANCA関連血管炎の壊死性病変部における NETs の存在と病的意義}

${ }^{1}$ 北海道大学 大学院保健科学研究院 病態解析学分野, ${ }^{2}$ 北海道大学 医学部保健学科 検查技術科学専攻, ${ }^{3}$ 市 立札幌病院 病理診断科, ${ }^{4}$ 北海道大学 死因究明教育 研究センター 病理学部門, ${ }^{5}$ 北海道大学 大学院医学 研究院 分子病理学教室, ${ }^{6}$ 聖マリアンナ医科大学皮虐 科

益田紗季子 ${ }^{1}$, 野々川莱佑 ${ }^{2}$, 西端友香 ${ }^{1}$, 岩崎沙理 ${ }^{3}$, 辻 隆裕 $^{3}$, 田中 敏 $^{4}$, 外丸詩野 ${ }^{5}$, 川上民裕 ${ }^{6}$, 石津明洋 ${ }^{1}$

【背景】ANCA関連血管炎の病態形成に好中球細胞外 トラップ（NETs）が関与していることが明らかとなっ ている。しかし，ANCAが関連しない血管炎や他の鑑 別疾患との対比研究はまた十分とは言えない。本研究 ではANCA関連血管炎の病変部に扔けるNETsについて 他の疾患と比較し，その病的意義を明らかにすること を目的とする。【方法】ANCA関連血管炎（MPA, GPA, EGPA）及びANCA非関連対照疾患として結節性多発 動脈炎（PAN）や皮膚動脈炎（CA），巨細胞性動脈炎 (GCA)，サルコイドーシスのホルマリン固定パラフィ ン包埋組織標本を用いて, シトルリン化ヒストンおよび 好中球（CD15）の蛍光免疫染色を行った。また，画像 解析にて病変部に占める NETs（シトルリン化ヒストン）
陽性面積の割合を求め, 各疾患で比較検討した。【結果】 ANCA 関連血管炎の血管炎病変部に見られるフィブリ ノイド壊死の周囲にNETs陽性所見が得られた。ANCA 関連壊死性動脈炎に打けるNETs陽性面積の割合は, ANCAが関連しないPANやCAの壊死性動脈炎，ならび に壊死を伴わないGCAの肉芽腫性血管炎に比べ有意に 高かった。GPAの肺の壞死性肉芽腫に招いてもNETs陽 性所見が得られ，病変部に占めるNETs陽性面積の割合 はサルコイドーシスの肉芽腫に比べ有意に高かった。 【考察】NETsはANCA 関連血管炎の壞死性病変部におい て, ANCAが関連しない壊死性動脈炎や壊死を伴わな い肉芽腫性病変部に比べて有意に多く形成されていた。 ANCA はNETs 産生を誘導すること，また，NETsは細胞 障害活性を有することが報告されており，ANCA関連血 管炎ではANCAにより誘導されたNETsが壊死性病変の 形成に関与している可能性が考えられる。

\section{1. 顕微鏡的多発血管炎の診断 13 年後に間質性肺 炎の急性増悪をきたし死亡した一剖検例}

${ }^{1}$ 東京都健康長寿医療センター 病理診断科, ${ }^{2}$ 国際医 療福祉大学病院 腎臓内科, ${ }^{3}$ 東京都健康長寿医療セン 夕ー 腎臟内科

柿㠃元恒 ${ }^{1}$, 松田陽子 ${ }^{1}$, 湯村和子 ${ }^{2}$, 野中敬介 ${ }^{1}$, 関 敦 子 $^{1}$, 橘 靖子 $^{3}$, 板橋美津世 ${ }^{3}$, 武井 卓 $^{3}$, 新井冨生 ${ }^{1}$

【症例】 81 歳女性。死亡 13 年前, 発熱と下腿浮腫のた め前医受診。タンパク尿，血尿抢よび腎機能低下を認 め, 画像上間質性肺炎が指摘された。MPO-ANCA陽性 であり, 腎生検では約半数の糸球体に細胞性半月体形 成を認めた。以上より顕微鏡的多発血管炎と診断され, ステロイドパルスとエンドキサンパルスが施行され， MPO-ANCA は陰転化し, 以後外来にて経過観察されて いた。死亡6ヶ月前より呼吸苦と発熱が出現し, KL-6上 昇（2139U/mL）と画像上間質性肺炎の増悪を認めたた め当院入院となった。抗菌薬とステロイドの投与によっ てKL-6值は低下傾向を示したが，呼吸状態は改善しな かった。MPO-ANCA は陰性，腎機能はCr 1.0台で経過 していた。死亡9日前より呼吸状態の急性増悪をきた し，永眠された。【剖検所見】両肺に抢いて間質性肺炎 およびびまん性肺胞傷害の像がみられ，直接死因と考元 られた。間質性肺炎は気管支・細気管支周囲の肺胞虚脱 による牽引性気管支拡張を伴う病態であった。全身臟器 に明らかな血管炎は認められず，頸部脂肪組織のごく一 部に陳旧化した血管病変を認めるのみであった。【まと 
め】臨床的にMPO-ANCA陰性を維持し, 腎病変の活動 性は抑えられていたが，間質性肺炎の急性増悪により死 亡した肺腎型（重症）顕微鏡的多発血管炎の一例であ る。剖検時には全身諸藏器に活動性の血管炎はみられ ず，腎糸球体病変は消失していた。顕微鏡的多発血管炎 の多くは腎障害を伴い，末期腎不全となり，透析導入に なると剖検が扔こなわれることは少ない。特に，肺病変 を伴う血管炎は，生命予後を規定する臟器障害になりう る可能性が高いことが示唆された。ANCA 関連血管炎の 治療による変化を考えるうえで貴重な症例と考元報告す る。

\section{2. 肺結節性病変の中に小血管炎と著明な好酸球浸 潤を認めたPR3-ANCA陽性の一例}

${ }^{1}$ 順天堂大学 病理 - 腫瘍学講座, ${ }^{2}$ 順天堂大学 人体病 理病態学講座

濱野慶朋 ${ }^{1}$, 梶野一徳 ${ }^{1}$, 林大久生 ${ }^{2}$, 佐伯春美 ${ }^{1}$, 松岡周

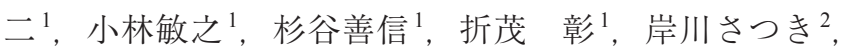
荒川 敦 ${ }^{2}$, 樋野興夫 ${ }^{1}$, 八尾隆史 ${ }^{2}$

症例は 54 歳女性。X年 10 月, 咳嗽が出現し近医を受 診したところ，右肺下葉に腫瘤性病変を指摘され，同月 に順天堂大学呼吸器内科を初診した。外来で気管支喘息 と診断。また画像上，右 $\mathrm{S} 8, \mathrm{~S} 9, \mathrm{~S} 10$ に長径 6〜38 $\mathrm{mm}$ の 結節性病変があり, 肺癌が疑われ，X年 12 月, $\mathrm{S} 10$ の病 変に対し CT ガイド下肺生検を行った。病変は小型血管 壁の弾性線維破壞と共に小型紡錘形細胞が膠原線維と 共に渦巻くように増生し，好酸球を主体とした炎症細 胞の浸潤を認めた。経過中，発熱・体重減少・末梢神 経症状 - 消化管症状 - 皮膚症状・筋関節症状はなかっ た。また，耳鼻科診察における上気道所見はなかった。 検查所見では，血中好酸球数 $1205 / \mu \mathrm{L}(13 \%), \operatorname{IgE} 30 \mathrm{IU} /$ $\mathrm{mL}$, MPO-ANCA $<1.0 \mathrm{U} / \mathrm{mL}$, PR3-ANCA $15.9 \mathrm{U} / \mathrm{mL}$, 抗核 抗体 $\times 40, \mathrm{RF}$ ・抗 CCP抗体は陰性だった。検尿でタンパ ク尿・血尿はなく，血清クレアチニン $0.71 \mathrm{mg} / \mathrm{dL} （ \mathrm{eGFR}$ $\left.66.4 \mathrm{~mL} / \mathrm{min} / 1.73 \mathrm{~m}^{2}\right)$, 炎症反応はなかった。肺癌マー カー（CEA, CYFRA, proGRP, SLX) は陰性, 感染症関連 検査（T-SPOT, $\beta$-D-グルカン，真菌抗原，HIV，ウイルス 肝炎）も全て陰性だった。画像上原発性もしくは転移性 肺癌が疑われたため, $\mathrm{X}+1$ 年 4 月, 右肺下葉切除術を施 行した。3つの結節性病変には, 細動脈壁への好酸球主 体の炎症細胞の浸潤と弾性板の破壊を認めた。血管壁の フィブリノイド壞死はなく, 肉芽腫性病変や巨細胞は認 められなかった。病変の中央部では紡錘形細胞が膠原線
維の増生と共に渦巻き状に増殖していた。周辺の肺胞 腔には好酸球の浸潤が目立ち, 好酸球性肺炎として矛 盾しない所見だった。ANCA関連血管炎や solitary fibrous tumor, 寄生虫症などを鑑別疾患として考慮し, 組織学 的所見を考察する。

\section{3. 小腸潰瘍・穿孔にて発症した好酸球性多発血 管炎性肉芽腫症（チャーグ・シュトラウス症候 群）の一例}

${ }^{1}$ 秋田大学大学院医学系研究科 器官病態学講座, ${ }^{2}$ 秋 田病理組織細胞診研究センター病理科, 3 雄勝中央病院 検査科

伊藤行信 ${ }^{1}$, 吉田 誠 $^{1}$, 杉山達朗 ${ }^{2}$, 増田弘毅 ${ }^{3}$, 後藤明 輝 ${ }^{1}$

\section{4. プロテアーゼによる抗系球体基底膜抗体病の隔} 絶抗原の表出

${ }^{1}$ 北海道大学 大学院保健科学研究院 病態解析学分野, ${ }^{2}$ 北海道大学 死因究明教育研究センター 病理学部門, 3 北海道大学 大学院医学研究院 分子病理教室

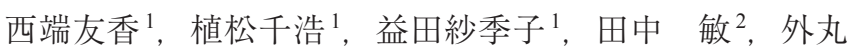
詩野 ${ }^{3}$, 石津明洋 ${ }^{1}$

抗糸球体基底膜抗体病（抗 GBM病）の抗原は，主に 糸球体や肺胞の基底膜を構成しているIV 型コラーゲン の $\alpha 3$ 鎖非コラーゲン領域 $\{\alpha 3(\mathrm{IV}) \mathrm{NC} 1\}$ に存在し, 通 常では立体構造的に隔絶された状態であることが知られ ている。抗 $\alpha 3(\mathrm{IV}) \mathrm{NC} 1$ モノクローナル抗体は, 正常ヒ 卜腎ホルマリン固定パラフィン包埋切片を用いた免疫組 織化学に扔いて，通常の抗原賦活化法では反応せず，酸 性条件下で熱処理を加えるか，プロテアーゼ処理を行う ことにより反応するようになる。酸性熱処理の意義と しては，加熱により直鎖化したタンパクの refolding 阻害 が，プロテアーゼ処理の意義としては，ホルマリン固定 によるタンパクのメチレン架橋除去が考えられている が，詳細は不明である。本研究では，精製IV 型コラー ゲンと抗 $\alpha 3(\mathrm{IV}) \mathrm{NC} 1$ モノクローナル抗体を用いて，免 疫ブロッティング法により $\alpha 3(\mathrm{IV}) \mathrm{NC} 1$ エピトープが表 出するメカニズムを検討した。非還元状態で加熱した IV 型コラーゲンをSDS-PAGEし，抗 $\alpha 3(\mathrm{IV}) \mathrm{NC} 1$ モノク ローナル抗体でウェスタンブロットすると, 約 $52 \mathrm{kDa}$ の 位置にバンドが検出された。それにプロテアーゼ処理 を加えると，バンドの位置は約 $42 \mathrm{kDa}$ に移動した。この ことから，プロテアーゼはIV型コラーゲンの分解を介 
して， $\alpha 3(\mathrm{IV}) \mathrm{NC} 1$ エピトープを表出させていると考え られた。抗GBM病は細菌感染を契機に発病することが 多い。細菌由来のプロテアーゼがIV型コラーゲンを分 解し，隔絶されているはずの抗原が表出することが抗 GBM病の病因となっている可能性も考えられる。

\section{5. 巣状壊死性静脈炎と系球体周囲の細動脈炎を合 併した，薬剤誘発性急性尿細管壊死の一例}

${ }^{1}$ 杏林大学 第一内科（腎臟・リウマチ膠原病内科）, 2 立正佼成会附属佼成病院, ${ }^{3}$ 杏林大学 病院病理部 増古紳太郎 ${ }^{1}$, 軽部美穂 ${ }^{1}$, 久木元光 ${ }^{1}$, 清水英樹 ${ }^{1}$, 福岡 利仁 ${ }^{1}$, 早川 哲 ${ }^{2}$, 小路 仁 $^{2}$, 下山田博明 ${ }^{3}$, 駒形嘉 紀 $^{1}$, 有村義宏 ${ }^{1}$, 要 伸也 $^{1}$

【症例】尿異常所見の既往がない38歳女性。10日前に 頭痛を自覚し、ロキソプロフェンナトリウム水和物の使 用を開始。7日前に一過性の膨疹を認めた。5日前に頭 痛に加え発熱, 嘔気を自覚し, 近医を受診。ロキソプロ フェンナトリウム水和物, クラブラン酸カリウム・アモ キシシリン水和物，エソメプラゾールマグネシウム水和 物の投薬加療をされた。3日前に乏尿, 下腿浮腫, $5 \mathrm{~kg} /$ 月の体重増加のため前医を受診。BUN $87.4 \mathrm{mg} / \mathrm{dL}, \mathrm{Cr}$ $9.06 \mathrm{mg} / \mathrm{dL}$ の急性腎障害にて入院となった。尿蛋白 $1+$, 沈查 RBC 0-1/HPF, WBC 20-29/HPF，顆粒 円柱+, NAG $13.6 \mathrm{U} / \mathrm{L}, \beta 2-\mathrm{MG} 1266 \mu \mathrm{g} / \mathrm{L}$ であった。腎尿路の形態異常, 腎萎縮は認めず，病歴から薬剤性急性尿細管壊死，間質 性腎炎を疑い，被疑薬の中止と保存加療を行った。しか し腎障害は改善せず，血液透析を開始した。当科へ転院 し，腎生検を施行。糸球体は 21 個で，全節性硬化なし。 毛細血管内腔は保たれ，管内・管外増殖，基底膜の異常 所見は認めなかった。間質の線維化は軽度で, 巣状にリ ンパ球，形質細胞主体の炎症細胞浸潤を認めた。尿細管 細胞の膨化，尿細管の萎縮，破壞性変化，傍尿細管毛細 血管炎を認めた。一部では肉芽腫様壊死性静脈炎，系球 体周囲の細動脈炎を認めた。蛍光免疫染色は陰性であっ た。その後腎機能は軽快し透析は離脱。ロキソプロフェ ンナトリウム水和物でDLST 陽性の結果を得た。【考察】 NSAIDs は薬剂誘発性急性腎障害の原因として知られて おり，急性尿細管壊死や急性間質性腎炎を呈する。一方 で，薬剤誘発性血管炎としての報告は稀である。本症例 はNSAIDsによる巣状壊死性静脈炎, 糸球体周囲の細動 脈炎を呈した興味深い症例と考え報告する。

\section{その他の血管研究}

座長：池田栄二（山口大学大学院医学系研究科病 理形態学講座)

\section{Pulmonary tumor thrombotic microangiopa- thy18剖検例の臨床病理学的検討}

${ }^{1}$ 産業医科大学 第 2 病理学教室, 2 産業医科大学病院 病理診断科, ${ }^{3}$ 産業医科大学 教育研究支援施設 共同 利用研究センター, ${ }^{4}$ 北九州総合病院 病理診断科 佐藤奈帆子 ${ }^{1}$, 田崎貴嗣 ${ }^{1}$, 名和田彩 ${ }^{1}$, 野口紘嗣 ${ }^{1}$, 木村

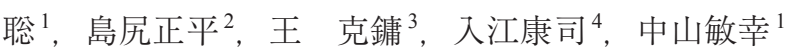

\section{7. 血清プロテオミクス法による敗血症の進行メカ ニズムの解明と機械学習を用いた診断法の開発}

${ }^{1}$ 東工大 院 生命理工， ${ }^{2}$ パナソニック株式会社， ${ }^{3}$ 日 大病院 臨床工学, ${ }^{4}$ 物質 - 材料研究機構 (NIMS) 分 子・物質合成プラットフォーム, ${ }^{5}$ 順天堂大 院 医

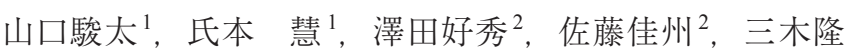
弘 $^{3}$ ，服部晋也 ${ }^{4}$, 射場敏明 ${ }^{5}$, 林 宣宏 $^{1}$

【背景・目的】敗血症に扮ける病態は感染した病原体 や患者の免疫応答により多岐に渡り，その変動は著し い。よって敗血症治療ではその重症度を経時的に判断す る事が必須である。これまでいくつかの血中マーカー が敗血症の病態評価に検討されたが，マーカーを選別し 個々に調查する従来の方針は精度や効率等の課題があっ た。そこで我々は独自に開発した高精度な血清プロテオ ミクス法を用いて, 敗血症患者の複数の血中タンパク質 の量や翻訳後修飾の変化を併せて, 経時的に評価するこ とによる，より高精度の診断を試みた。さらに敗血症患 者の二次元電気泳動画像に含まれる情報をすべて活用す るために，機械学習による病態の人工知能を用いた診断 を検討した。【方法】敗血症20症例について, ICU入室 初日から 7 日後まで各 5 点での血清から 14 種類の大量含 有タンパク質を除去した後, 二次元電気泳動を行い, 含 有タンパク質の経時的な変化を調べた。【結果・考察】 経時変化は同一個人内で調べた。敗血症の進行に伴い量 的変化が見られたタンパク質を，その変化パターンによ りクラスタリングした結果，それぞれのタンパク質を関 わる生体反応ごとに分けられた。新たに明らかになった グループの中には、これまで知られていなかった生理現 象が敗血症の進行に伴い起きていることを示唆するもの もあった。また，機能が未知のタンパク質がいずれかの グループに属した場合には，そのタンパク質の機能が類 
推できるだけでなく，未知のカスケードの存在を示唆 する場合もあった。A.I.による病態の将来予測に関して は, 現時点のSOFA スコアと二次元電気泳動像から将来 のSOFAスコアの予測を試みた。その結果, SOFA スコ アそのものの予測はできなかったが, SOFAスコアを構 成する項目のうち，心血管と腎機能のスコアについては 二次元電気泳動像を用いることの有意性が示された。こ のことは, 学習デー夕数を増やして機械学習を行えば, より精度の高い病態変化の予測がA.I.により行える可能 性を示している。

\section{8. 卵巣奇形腫の病理学的悪性度と奇形腫内血管の h-Caldesmon 陽性率との逆相関}

東京医科大学 分子病理学分野 小濱政子，倉田 厚，黒田雅彦

【背景】近年我々は, h-Caldesmon（h-CD）が血管平滑 筋に打いて多様な発現を呈し，不安定プラークはh-CD 陰性の未熟な平滑筋が主体であると報告した。一方で, h-CDが成熟平滑筋のみで陽性となることは，婦人科や 軟部の平滑筋系腫瘍では報告されているものの，血管 ではまだ研究されていない。そこで，卵巣奇形腫（悪 性度=未熟度に応じて grade 0 4 と分類：神経管の多寡 で決定）の検体を用いて，その悪性度と血管平滑筋に おける h-CDの陽性率を検討した。【対象と方法】5例の

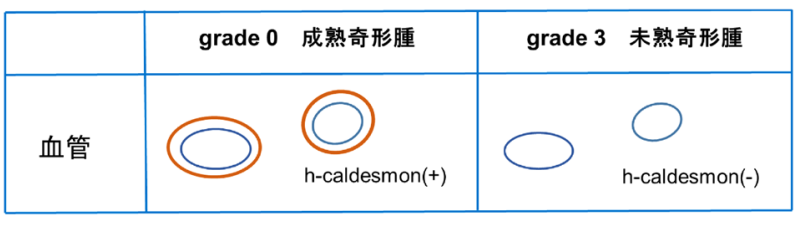

図1 本研究の結果のまとめ

成熟奇形腫（grade 0）と16例の未熟奇形腫（grade 1: 5 名, grade 2: 6名 grade 3:5名）の検体を対象とし, CD31, $\alpha$-SMA, h-CDにより免疫染色した。CD31 陽性管腔構造 を血管とみなして数を測定し, 同構造における $\alpha$-SMA (全平滑筋に発現), h-CD（成熟平滑筋のみに発現と想 定）陽性数を測定し $\alpha-S M A / C D 31, h-C D / C D 31$ 及びh-CD/ $\alpha$-SMA 比を算出した。【結果】 $\alpha$-SMA/CD31 比は grade 0 と3の間を除き，群間の差はみられなかった。一方， h-CD/CD31 比およびh-CD/ $\alpha$-SMA 比はgradeが高くなる ほど低值となり（図1），両比とも grade 0 および 1 より grade 2 抢よび3において有意に低い值となった。【結論】 血管平滑筋の $\mathrm{h}-\mathrm{CD}$ 発現率は奇形腫組織の成熟度と相関 していることが明らかになり，h-CDは血管においても 平滑筋の成熟度のマーカーとなることが示唆された。ま た，現状，病理医が主観で判定しており必ずしも再現性 が良好ともいえない神経管の量測定による奇形腫未熟度 （悪性度）判定に対し一石を投じる，新しい診断手法に なりうること, 特に術後化学療法の適応の可否の分かれ 目となる grade 1 と 2 の判別に役立つことが示唆された。 